$@$ ERSpublications

There should be a procedure for certification of sleep centres and physicians http://ow.ly/HLGm3

Josep M. Montserrat ${ }^{1,2}$, Joaquin Terán-Santos ${ }^{1,2}$ and F. Javier Puertas ${ }^{1}$

${ }^{1}$ Spanish Committee of Sleep Medicine (CEAMS), Madrid, Spain. ${ }^{2}$ CIBERES, Madrid, Spain.

Correspondence: Josep M. Montserrat, Sleep Unit, Hospital Clinic, C/ Villarroel 170, Barcelona 08036, Spain. E-mail: jmmontserrat@ub.edu

Received: Oct 102014 | Accepted: Dec 052014

Conflict of interest: None declared.

\title{
References
}

1 Quan SF, Buysse DJ, Ward SL, et al. Development and growth of a large multispecialty certification examination: sleep medicine certification - results of the first three examinations. J Clin Sleep Med 2012; 8: 221-224.

2 American Board of Internal Medicine. Sleep medicine policies. www.abim.org/certification/policies/imss/sleep.aspx

3 Parthasarathy S, Haynes PL, Budhiraja R, et al. A national survey of the effect of sleep medicine specialists and American Academy of Sleep Medicine Accreditation on management of obstructive sleep apnea. J Clin Sleep Med 2006; 2: 133-142.

4 Deutschen Gesellschaft für Schlafforschung und Schlafmedizin. Qualifikationsnachweis Somnologie [Certification of qualification in somnology]. Somnologie 1997; 1: 97-100.

5 Penzel $\mathrm{T}$, Hein $\mathrm{H}$, Rasche $\mathrm{K}$, et al. Leitfaden für die Akkreditierung von schlafmedizinischen Zentren der Deutschen Gesellschaft für Schlafforschung und Schlafmedizin (DGSM) [Instructions for the accreditation of sleep centers of the German Sleep Society]. Somnologie 2000; 4: 181-187.

6 Bahammam AS, Al-Jahdali $\mathrm{H}$, Alharbi AS, et al. Saudi regulations for the accreditation of sleep medicine physicians and technologists. Ann Thorac Med 2013; 8: 3-7.

7 Penzel T, Pevernagie D, Dogas Z, et al. Catalogue of knowledge and skills for sleep medicine. J Sleep Res 2014; 23: 222-238.

8 Fischer J, Dogas Z, Bassetti CL, et al. Standard procedures for adults in accredited sleep medicine centres in Europe. J Sleep Res 2012; 21: 357-368.

9 Guerrero A, Embid C, Isetta V, et al. Management of sleep apnea without high pretest probability or with comorbidities by three nights of portable sleep monitoring. Sleep 2014; 37: 1363-1367.

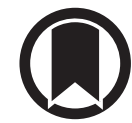

CrossMark

\section{Prevalence of Birt-Hogg-Dubé syndrome in patients with apparently primary spontaneous pneumothorax}

To the Editor:

Pneumothorax is classified "spontaneous pneumothorax" if there is no external force causing it and is classified as "primary spontaneous pneumothorax" (PSP) if there is no underlying lung disease. According to the guidelines of the British Thoracic Society (BTS), "no underlying lung disease" is based on history, physical examination and chest radiography [1].

Several years ago we evaluated the site of cystic lesions by thoracic computed tomography (CT) (slice thickness $10 \mathrm{~mm}$ ) in a group of 101 PSP patients. These lesions were described as blebs and bullae, and defined as air-containing thin-walled spaces in the pulmonary parenchyma [2]. The most common area found was subpleural in the upper lobes; however, in a minority (5\%), only small cystic lesions were found below the level of the main carina.

To confirm this finding in a more recent cohort, we reviewed the cohorts of PSP patients from a general and a university hospital. In 69 patients, CT had been performed within 1 year before or after the PSP and all CTs were scored on the presence of cyst(s) below the level of the carina. The mean age of the whole group was 37.6 years, the recurrence rate was $28.2 \%$ and a positive family history of spontaneous pneumothorax was noted in $16.2 \%$ of cases. In seven (10\%) patients, $>50 \%$ of the cysts were located below the level of the carina (table 1). 


\begin{tabular}{|c|c|c|c|c|c|c|c|c|c|}
\hline $\begin{array}{l}\text { Patient with }>50 \% \\
\text { of cysts under the } \\
\text { carina }\end{array}$ & $\begin{array}{l}\text { Sex lage at } \\
\text { first PSP } \\
\text { years) }\end{array}$ & \multicolumn{2}{|c|}{ Recurrence of PSP } & $\begin{array}{l}\text { Recurrences of } \\
\text { PSP } n\end{array}$ & $\begin{array}{l}\text { Lung cysts } \\
\text { under } \\
\text { carina n (\%) }\end{array}$ & $\begin{array}{c}\text { Renal-cell cancer } \\
\text { lage at diagnosis } \\
\text { years) }\end{array}$ & FF & $\begin{array}{l}\text { Family } \\
\text { history of } \\
\text { SP }\end{array}$ & FLCN mutation ${ }^{\#}$ \\
\hline 1 & $M(24)$ & \multicolumn{2}{|l|}{ Yes } & 3 & $6(81)$ & Yes (44) & No & No & c. $510 C>$ G; p.Tyr170X \\
\hline 2 & $F(20)$ & \multicolumn{2}{|l|}{ Yes } & 8 & $13(84)$ & No & No & No & $\begin{array}{c}\text { c.610_611delGCinsTA p. } \\
\text { Ala240X }\end{array}$ \\
\hline 3 & $M(62)$ & \multirow{2}{*}{\multicolumn{2}{|c|}{ No }} & & $10(100)$ & NA & NA & NA & Not tested \\
\hline 4 & $M(75)$ & & & & $3(100)$ & Yes (74) & NA & NA & Not tested \\
\hline 5 & $M(20)$ & \multicolumn{2}{|l|}{$\begin{array}{l}\text { No } \\
\text { Yes }\end{array}$} & 2 & $3(67)$ & NA & NA & NA & Not tested \\
\hline 6 & $M(29)$ & \multicolumn{2}{|l|}{ No } & & $4(75)$ & NA & NA & NA & Not tested \\
\hline 7 & $F(52)$ & \multicolumn{2}{|l|}{ No } & & $35(52)$ & NA & NA & No & Not tested \\
\hline $\begin{array}{l}\text { Patient with BHD } \\
\text { syndrome } \\
\text { (family) }\end{array}$ & $\begin{array}{l}\text { Sex lage at } \\
\text { first PSP } \\
\text { years) }\end{array}$ & $\begin{array}{c}\text { Delay between first } \\
\text { symptom of PSP and } \\
\text { final diagnosis of BHD } \\
\text { (months) }\end{array}$ & $\begin{array}{l}\text { Recurrence } \\
\text { of PSP }\end{array}$ & $\begin{array}{l}\text { Recurrences of } \\
\text { PSP } n\end{array}$ & $\begin{array}{l}\text { Lung cysts } \\
\text { n }\end{array}$ & Renal tumour & FF & $\begin{array}{l}\text { Smoking } \\
\text { history }\end{array}$ & FLCN mutation \\
\hline $1(84)$ & $F(20)$ & 243 & Yes & 8 & 13 & No & Minimal" ${ }^{ף}$ & No & $\begin{array}{c}\text { c.610_611delGCinsTA } \\
\text { (p.Ala240X) }\end{array}$ \\
\hline $2(85)$ & $M(26)$ & 153 & Yes & 6 & 140 & No & Minimal" & No & $\begin{array}{c}\text { c.1408_1418del (p. } \\
\text { Gly470fs) }\end{array}$ \\
\hline $3(94)$ & $M(40)$ & 81 & Yes & 3 & 74 & No & No & No & c. $1539-2 A>G$ \\
\hline
\end{tabular}


These results confirm our earlier findings and might be important because this location of lung cysts is found in a disease with a high frequency of (recurrent) pneumothorax, the Birt-Hogg-Dubé (BHD) syndrome [3].

BHD syndrome is an autosomal dominant condition caused by germline mutations in the folliculin (FLCN) gene, and further characterised by skin fibrofolliculomas and a high risk of renal-cell cancer. Clinical manifestations of BHD syndrome are variable, and spontaneous pneumothorax may be the first and only manifestation of BHD syndrome in isolated and familial cases [4-8]. As most BHD patients have normal lungs on chest radiography and neither impairment of pulmonary function nor pulmonary complaints prior to the pneumothorax, based on history, physical examination and chest radiography, a pneumothorax will most likely be classified as PSP [1].

We performed a pilot study to test whether the CT-detected rate of cysts below the main carina in 5-10\% of PSP patients might be caused by undiagnosed BHD syndrome in PSP patients. A questionnaire was sent out to patients previously (between 2000 and 2013) diagnosed with PSP, based on BTS criteria [1]. We invited them to participate voluntarily in a pilot study in which CT of the thorax and FLCN mutation analysis were performed. The number of participants was restricted to 40 . This study was approved by the ethics committee of the VU University Medical Center, Amsterdam, the Netherlands (NL31417.029.10). All patients provided written informed consent.

Cysts were found below the level of the main carina in three patients and all three had a pathogenic FLCN mutation (7.5\%, 95\% CI 1.5-20.3\%). The FLCN mutations detected in these patients were a nonsense mutation (c.610_611delGCinsTA (p.Ala240X)), a frameshift mutation (c.1408_1418del (p.Gly470fs)) and a splice site mutation (c.1539-2A>G) (table 1). After being diagnosed in this study, one of these patients was presented as a case report illustrating the characteristic findings in a BHD syndrome patient [8].

According to current guidelines for BHD syndrome [9], family members were invited for mutation analysis and four additional FLCN mutation carriers (one each in families A and B, and two in family C) were found. Subsequently magnetic resonance imaging (MRI) of the kidneys was performed. One of them had an asymptomatic, 15-mm solid mass on renal MRI. Further analysis revealed a clear-cell renal-cell carcinoma that was treated with nephron-sparing therapy. Among the 37 cases with PSP without the pathogenic FLCN mutation, no cysts were found in the basal parts of the lungs.

Our findings are in line with a previously reported prospective study in a Chinese population with PSP. REN et al. [10] found 10 (9.8\%) patients with a pathogenic FLCN mutation among an unselected cohort of 102 PSP patients. Unfortunately, extensive details on radiological findings were not reported.

Our retrospective evaluation of CTs of PSP patients shows that cysts in the basal parts of the lung are relatively rare (frequency up to $10 \%$ ) but could be an important finding as these patients may have BHD syndrome. In our pilot study, we confirmed earlier findings in a Chinese population that BHD syndrome might be responsible for pneumothorax in up to $10 \%$ of the PSP patients.

With current guidelines, this diagnosis will most probably be missed among PSP patients. This raises the question of whether CT should become a part of the diagnostic investigations in patients presenting with PSP. Arguments to support this are not only the high recurrence rate in BHD, which makes it attractive to treat these patients at the first pneumothorax much more aggressively than according to guidelines for PSP [11], but also the possibility to detect, through an affected pneumothorax patient, more family members with the pathogenic mutation and initiate life-long yearly screening of the kidneys in all carriers as the risk of developing renal-cell cancer is high [12]. Based on our database and the literature, it is likely that detecting a BHD syndrome family through a pneumothorax case will result in early diagnosis of renal-cell cancer in a large number of affected cases [13].

In summary, current guidelines for PSP result in underdiagnosis of BHD syndrome. BHD syndrome is probably the cause of the pneumothorax in $5-10 \%$ of PSP cases. Diagnosis of BHD syndrome will improve early detection of renal-cell cancer in these patients as well as in affected relatives.

@ERSpublications

Birt-Hogg-Dubé syndrome is probably the cause of pneumothorax in $5-10 \%$ of primary spontaneous pneumothorax patients http://ow.ly/FiIGS

Paul C. Johannesma ${ }^{1}$, Rinze Reinhard ${ }^{2}$, Yael Kon ${ }^{3}$, Jincey D. Sriram ${ }^{4}$, Hans J. Smit ${ }^{4}$, R. Jeroen A. van Moorselaar ${ }^{5}$, Fred H. Menko ${ }^{6}$ and Pieter E. Postmus ${ }^{1}$ on behalf of the Amsterdam BHD working group ${ }^{7}$

${ }^{1}$ Dept of Pulmonary Diseases, VU University Medical Center, Amsterdam, The Netherlands. ${ }^{2}$ Dept of Radiology, VU University Medical Center, Amsterdam, The Netherlands. ${ }^{3}$ Dept of Dermatology, VU University Medical Center, Amsterdam, The Netherlands. ${ }^{4}$ Dept of Pulmonary Diseases, Rijnstate Hospital, Arnhem, The Netherlands. ${ }^{5}$ Dept of Urology, VU University Medical Center, Amsterdam, The Netherlands. ${ }^{6}$ Family Cancer Clinic, The Netherlands Cancer Institute, Amsterdam, The Netherlands. ${ }^{7}$ For a list of the additional participating principal investigators of the 
Amsterdam BHD working group and their affiliations, see the Acknowledgements section.

Correspondence: Pieter E. Postmus, Dept of Pulmonary Diseases, VU University Medical Center, PO Box 7057, 1007 MB Amsterdam, The Netherlands. E-mail: pe.postmus@vumc.nl

Received: Aug 012014 | Accepted: Nov 272014

Clinical trial: This study is registered at www.toetsingonline.nl with identifier number NL31417.029.10

Support statement: No funding was provided for this study.

Conflict of Interest: None declared.

Acknowledgements: The additional participating principal investigators of the Amsterdam BHD working group were Marianne A. Jonker (Dept of Epidemiology and Biostatistics, VU University Medical Center, Amsterdam the Netherlands), Arjan C. Houweling (Dept of Clinical Genetics, VU University Medical Center), Quinten Waisfisz (Dept of Clinical Genetics, VU University Medical Center), Johannes J.P. Gille (Dept of Clinical Genetics, VU University Medical Center), Erik Thunnissen (Dept of Pathology, VU University Medical Center), JanHein T.M. van Waesberghe (Dept of Radiology, VU University Medical Center) and Theo M. Starink (Dept of Dermatology, VU University Medical Center).

We are grateful to all included pneumothorax patients who participated in this study.

\section{References}

1 MacDuff A, Arnold A, Harvey J, et al. Management of spontaneous pneumothorax: British Thoracic Society Pleural Disease Guideline 2010. Thorax 2010; 65: Suppl 2, ii18-ii31.

2 Smit HJ, Wienk MA, Schreurs AJ, et al. Do bullae indicate a predisposition for recurrent pneumothorax? $\mathrm{Br} J$ Radiol 2000; 73: 356-359.

3 Johannesma PC, van Waesberghe JHTM, Reinhard R, et al. Chest CT for primary spontaneous pneumothorax (PSP): findings: Birt-Hogg-Dubé versus non-Birt-Hogg-Dubé patients. Am J Respir Crit Care Med 2014; 189: A6415.

4 Johannesma PC, Lammers JW, van Moorselaar RJ, et al. Spontaneous pneumothorax as the first manifestation of a hereditary condition with an increased renal cancer risk. Ned Tijdschr Geneeskd 2009; 153: A581.

5 Pierce CW, Hull PR, Lemire EG, et al. Birt-Hogg-Dubé syndrome: an inherited cause of spontaneous pneumothorax. CMAJ 2011; 183: E601-E603.

Verhaert LL. A young man with bilateral spontaneous pneumothorax. Case Rep Pulmonology 2011; 2011: 414165.

Hopkins TG, Maher ER, Reid E, et al. Recurrent pneumothorax. Lancet 2011; 377: 1624.

Johannesma PC, Thunnissen E, Postmus PE. Lung cysts as indicator for Birt-Hogg-Dubé syndrome. Lung 2014; 1952: 215-216.

9 Menko FH, van Steensel MA, Giraud S, et al. Birt-Hogg-Dubé syndrome: diagnosis and management. Lancet Oncol 2009; 10: 1199-1206.

10 Ren HZ, Zhu CC, Yang C, et al. Mutation analysis of the FLCN gene in Chinese patients with sporadic and familial isolated primary spontaneous pneumothorax. Clin Genet 2008; 74: 178-183.

11 Johannesma PC, Jonker MA, van der Wel MA, et al. Management of spontaneous pneumothorax in patients with or without Birt-Hogg-Dubé syndrome. Eur Respir J 2014; 44: Suppl. 58, 752.

12 Houweling AC, Gijezen LM, Jonker MA, et al. Renal cancer and pneumothorax risk in Birt-Hogg-Dubé syndrome; an analysis of 115 FLCN mutation carriers from 35 BHD families. Br J Cancer 2011; 105: 1912-1919.

13 Johannesma PC, Houweling AC, Reinhard R, et al. Early detection of hereditary renal cell cancer by improved evaluation of spontaneous pneumothorax patients. Ann Oncol 2014; 25: Suppl. 4, iv254.

\section{Inherent weaknesses of the current ICD coding system regarding idiopathic pulmonary fibrosis}

\section{To the Editor:}

Idiopathic pulmonary fibrosis (IPF) is the most prevalent of the idiopathic interstitial pneumonias (IIPs). It carries an ominous prognosis with a median survival of 3 years. Its epidemiology is poorly described because of its rarity and lack of unanimity in diagnostic and coding practices [1]. However, during the last few years, significant improvement has been achieved in our understanding of the pathogenesis, diagnosis 